\title{
Echar raíces en tierra fértil. Producciones, domesticidad y memorias de familias rurales en la colonización tardía argentina (medianos de siglo XX) ${ }^{1}$
}

\begin{abstract}
Resumen
Desde la primera mitad del siglo XX se comenzaron a consolidar preocupaciones sobre los problemas reales y/o potenciales que el éxodo rural y la superpoblación urbana podían traer aparejados. Esta vertiente de pensamiento se afianzó luego durante la segunda posguerra, tanto en ámbitos académicos como en la dirigencia política internacional, donde se discurría sobre aspectos poblacionales, territoriales y alimenticios vinculados. La Argentina, en un contexto latinoamericano que no quedó al margen de tales debates, se sumó a diferentes propuestas de contraurbanización que alentaban la desconcentración y el asentamiento de núcleos familiares en entornos rurales cercanos a las ciudades. En ese sentido, la creación de colonias agrícolas de perfil intensivo con base en el trabajo familiar fue una de las más resonadas. Aunque estas iniciativas recibieron atención de la historiografía desde diferentes ángulos, las familias intervinientes y sus aportes usualmente permanecieron relegadas. En ese sentido, el propósito del presente estudio es reponer en el panorama a los sujetos a los que se dirigían las propuestas, es decir, a las familias, con énfasis en desentrañar prácticas productivas y rasgos de la vida doméstica, especialmente con atención en las experiencias según el género. Con ese objetivo se trabajará sobre dos casos de colonias agrícolas periurbanas formadas en 1951 ("17 de octubre/La Capilla" y "Justo José de Urquiza") en dos partidos cercanos a la capital de la provincia de Buenos Aires, La Plata, y la Capital Federal.
\end{abstract}

Palabras clave: Familias Rurales. Colonización. Vida Doméstica. Memoria. Argentina - História.

\section{Para citar este artículo:}

DE MARCO, Celeste. Echar raíces en tierra fértil. Producciones, domesticidad y memorias de familias rurales en la colonización tardía argentina (medianos de siglo XX). Tempo e Argumento, Florianópolis, v. 11, n. 28, p. 8 - 46, set./dez. 2019.

\section{DOI: $10.5965 / 2175180311282019008$}

http://dx.doi.org/10.5965/2175180311282019008

\footnotetext{
${ }^{1}$ El presente estudio deriva de una tesis doctoral presentada en la Universidad Nacional de Quilmes (Buenos Aires, Argentina) en 2018, realizada con el respaldo de una beca doctoral CONICET. Agradezco la orientación brindada por la Dra. Talía Gutiérrez, los comentarios del jurado (Dra. Mónica Blanco, Dra. Isabella Cosse, Dra. Martha Ruffini), las sugerencias de los/las evaluadores(as) anónimos(as) y en especial a cada entrevistado(a) por su valioso tiempo.
} 


\section{Taking roots in fertile land. Productions, domesticity and memories of rural families in late Argentine colonization (mid-twentieth century)}

\author{
Enraizar-se em terra fértil. \\ Produções, domesticidade e \\ lembranças de famílias rurais \\ no final da colonização \\ argentina (meados do século \\ $\mathrm{XX})$
}

\section{Resumo}

Desde meados do século XX começaram a se consolidar preocupações sobre os problemas (reais o imaginários) que o êxodo rural e a superpopulação urbana poderiamtrazer. Esta linha de pensamento é reforçada durante a Segunda Guerra Mundial, tanto no meio acadêmico e na liderança política internacional, onde foram discutidos problemas de população, territoriais e aspectos nutricionais ligados. Argentina, em um contexto latino-americano que não foi deixado de fora de tais debates, juntou varias propostas que incentivou a descentralização em cidades perto de ambientes rurais. Nesse sentido, a criação de colônias agrícolas intensivas baseadas no trabalho familiar foi uma das mais contundentes. Embora essas iniciativas tenham recebido atenção da historiografia de diferentes ângulos, as famílias intervenientes e suas contribuições geralmente permaneceram relegadas. Nesse sentido, o objetivo deste estudo é retratar famílias nesses cenários, com destaque para revelar práticas produtivas e traços da vida doméstica, especialmente com atenção às experiências de acordo com o gênero. Para o efeito, vamos trabalhar em dois casos de colônias agrícolas periurbanas formadas em 1951 ("17 de Octubre / La Capilla" e "Justo José de Urquiza") perto da capital nacional e da província de Buenos Aires, La Plata.

Palavras-chave: Famílias Rurais. Colonização. Vida Doméstica. Memória. Argentina.
Keywords: Rural families. Colonization. Domestic Life. Memory. Argentina. 


\section{Introducción}

En las siguientes páginas se estudia a un grupo de familias rurales que vivieron en colonias agrícolas creadas durante el peronismo (1946-1955) en espacios rurales cercanos a lo urbano. Estos emprendimientos se concretaron cuando aún gravitaba el lema "la tierra para el que la trabaja", reverberaban discusiones sobre políticas de tierras y preocupaba la producción alimentaria, a partir de las reconvenciones dejadas por la segunda posguerra.

Las familias colonas, que eran la base de esos emprendimientos, aparecieron flanqueadas por una política que supo tener un brillante desarrollo decimonónico pero que entraría -con altibajos- en franco retroceso. A su vez también se vieron inmersas por tradicionales representaciones sobre el campo y una explícita cercanía con lo urbano que imprimiría su impronta en su día a día como característica de una modalidad específica en la creación de colonias.

Si bien la historiografía rural mostró sugerentes resultados en cuanto al estudio de las políticas de tierras como también de las familias, en general se identifican espacios vacantes que impulsan preguntas. En ese sentido, ¿qué se puede decir sobre quienes habitaron en espacios rurales colonizados de forma tardía, donde lo rural se fundía de formas variables con lo urbano? Se trata, pues, de sujetos familiares poco vistos dentro de un entramado rural que sigue revelando hilos ocultos. En ese sentido, la intención es contribuir a su reconstrucción en la medida en que su invisibilidad contrasta con el hecho de que formaron parte de una política y una discursividad de notable duración en torno del campo en Argentina.

El análisis se concreta a través de los casos de las colonias "La Capilla" y "Justo José de Urquiza", ubicadas en los partidos de Florencio Varela y La Plata respectivamente, al sur de la capital federal. La primera fue fundada por el Instituto Autárquico de Colonización (IAC) de la provincia de Buenos Aires, y la segunda por el Banco de la Nación Argentina (BNA). El estudio abarca tres décadas (1950-1970) en las cuales ambos emprendimientos mostraron rasgos sintomáticos de crecimiento que comenzarían a desaparecer o transformarse a partir de 1980, ante un nuevo escenario socioeconómico (DE MARCO, 2018a). 
En ese contexto, se pone atención en las prácticas productivas, pero sobre todo en la vida doméstica, de modo que la cotidianidad se convierte en una cuestión central. Se parte de la familia como unidad de análisis para abordar su instalación, organización y distribución de tareas según edad y género, cuestiones que permiten reflexionar sobre el arraigo, nodo central de la política colonizadora en que las familias quedaron contenidas. El enfoque propuesto implica reparar en miradas institucionales y de la prensa. Se pretende así desvelar tramas que hacen converger políticas, tierras y vidas familiares en la Argentina de mediados del siglo XX. Se recurre a los recuerdos de los propios productores -ex colonos $-^{2}$ como fuentes de particular interés.

Finalmente se sostiene que hubo modos de vivir en familia, de producir y vincularse sinérgicamente con el entorno que fueron característicos de este tipo de colonias, las cuales presentan similitudes pero también sensibles diferencias que devuelven una mirada más compleja de la política matriz que les dio origen, como también del espacio periurbano. Asimismo, estas prácticas basadas en la diversidad de los grupos familiares fueron fundamentales para construir tramas comunales que derivaron en la historia de éxitos o fracasos, contextos en los que anclaron experiencias y memorias que permiten recomponer figuras soterradas e invisibilizadas del espacio rural argentino.

\section{Colonización agrícola, un escenario (1950-1970)}

Hacia mediados del siglo XX la intención de promover la producción alimentaria avanzó sobre el mermado escenario internacional de posguerra, en el que los espacios rurales cercanos a entornos urbanos se perfilaron como interesantes proveedores. En respuesta se diseñaron diferentes propuestas oficiales, algunas de las cuales incluían la gestión de colonias agrícolas. De esta suerte, se abría un panorama que involucraba

\footnotetext{
${ }^{2}$ El trabajo de campo se realizó entre 2012-2018, en el marco de una tesis de licenciatura y posteriormente una tesis doctoral. Los registros de las entrevistas fueron aproximadamente 35, entre mujeres y varones. La selección se hizo recurriendo a la noción de informante clave, a través de un muestreo en cadena. Por otra parte, podría plantearse si el uso de esta categoría es válido, sobre todo cuando se advierte que la mayoría de los testimonios pertenecen a quienes ingresaron siendo niños, o incluso bebés, a las colonias. Al respecto es importante la aclaración de que todos los entrevistados se desempeñaron durante una parte de sus vidas en las labores del lote, siendo ellos mismos con sus propias familias o por sí mismos productores.
} 
familias productoras como principales encargadas de ejecutar las labores, de modo que tanto en el plano de las ideas como en la práctica, una política y un sujeto quedaban inextricablemente unidos.

En verdad, Argentina tenía una nutrida historia previa ligada a la formación de colonias en el siglo XIX. Pero a diferencia de tiempos pasados cuando los impulsos colonizadores habían sido pensados para promover producciones cerealeras, poblar y sojuzgar territorios, en el siglo XX se perfilaban otras pretensiones. Los contornos citadinos de rasgos rurales aparecieron como claves para la provisión alimentaria, pero también como barrera de contención contra el éxodo rural.

En efecto, Argentina no solo no quedó al margen de planteos que alentaban movimientos centrífugos y desconcentradores de población, sino que decantó en ellos fomentando diferentes variantes de obras colonizadoras que incluía la mencionada de rasgos periurbanos. Lo anterior se conjugó con una serie de profundos procesos sociodemográficos, económicos y productivos que transformaron el Área Metropolitana de Buenos Aires (AMBA) desde la década de 1940.3

De esta suerte, la colonización presentó un carácter complejo e interesante. Posiblemente se trate de una de las escasas políticas públicas en Argentina que, desarrollada durante un extenso período -con vaivenes, no pocos fracasos y períodos de inacción- tuvo por objeto específico a la familia, no solamente rural, para favorecer su asentamiento en el campo, la subdivisión de la propiedad y el incentivo a determinado tipo de producciones, en especial las de tipo intensivo.

\footnotetext{
${ }^{3}$ La construcción histórica del espacio periurbano puede profundizarse en estudios como GUTMAN, Pablo, GUTMAN, Graciela y DASCAL, Guillermo. El campo en la ciudad: la producción agrícola en el gran Buenos Aires. Buenos Aires: CEUR, 1987; BARSKY, Andrés. (2011). La agricultura de 'cercanías' a la ciudad y los ciclos del territorio periurbano. Reflexiones sobre el caso de la Región Metropolitana de Buenos Aires. In: NEMIROVSKY, Ada Svetlitza de (coord.) Globalización y agricultura periurbana en Argentina: escenarios, recorridos y problemas. Buenos Aires: FLACSO, 2011. pp. 15-30, y BENENCIA, Roberto. Transformaciones en la horticultura periurbana bonaerense en los últimos cincuenta años. El papel de la tecnología y la mano de obra. Periferia Activa [Blog], agosto 2012. Recuperado de: https://periferiaactiva .files.wordpress.com/2012/08/roberto-benecencia.pdf.
} 
Más allá de los antecedentes finiseculares y el auge de las discusiones, incluso durante el periodo conservador, en los primeros tres años de presidencia de Juan D. Perón la "reforma agraria" pregonada en la etapa preelectoral parecía continuar en diálogo con un modelo de promoción industrial que tomaba sus recursos del sector agrícola. Sin embargo, estos avances se vieron limitados en 1949 cuando se procuró aumentar la producción agraria (GIRBAL-BLACHA, 2002). En ese contexto, el BNA fue el organismo encargado de ejecutar obras de colonización agrícola a nivel nacional en reemplazo del CAN desde 1946 (1940).

Se avecinaba, sin embargo, un futuro menos brillante en el que la prioridad sería racionalizar las explotaciones y aumentar la producción agraria. En esa línea de acontecimientos en 1954 los nuevos intereses se cristalizaron en el ámbito normativo con la nueva Ley de Colonización, escrita en un tono mucho más conservador. A través de la nueva legislación el Estado podría intervenir en la distribución y uso de las propiedades para regentear su rendimiento y facilitar a los trabajadores la obtención de sus propias tierras, en un orden en el que el acceso a la propiedad quedaba subsumido en la productividad. Sin embargo, cierto impulso seguía teniendo lugar y se concretaron algunas colonias, como la antes mencionada “Justo José de Urquiza” (1951).

Como correlato, la provincia de Buenos Aires fue inicialmente conducida por el sendero de una industrialización mercado-internista al tomar recursos del sector agro para dirigirlos a pequeñas y medianas industrias (MATEO, 2005). Al mismo tiempo, el gobernador Domingo A. Mercante (1946-1952) pronunciaba elocuentes discursos que manifestaban su preocupación por cuestiones como la superpoblación urbana, el desempleo y el éxodo rural aun activo. En este contexto no dudó en alentar la colonización, de modo que en el inicio de sesiones de la Legislatura Bonaerense de 1947 expresó que esta política se encontraba entre las preocupaciones centrales de su mandato (BUENOS AIRES, 1948). En efecto, en el transcurso de su gobernación tuvo un interesante despliegue e incluso en agosto de 1947 se presentó en la Cámara de Diputados una propuesta para darle nuevo aliento al IAC, que había sido creado en 1936 pero no se hallaba al momento en funciones. No obstante, la gobernación de su sucesor, Carlos Aloé (1952-1955), significó un retroceso en la medida en que adhirió a los cambios 

sería rebautizada de forma más aséptica como "La Capilla”.

El golpe cívico-militar declamado “Revolución Libertadora” (1955-1957) introdujo una nueva ruptura a la vida democrática. En esta línea sus conductores encontraron que debían modificar el curso de varias cuestiones y el agro no quedaría al margen. En ese sentido, se potenció una economía agraria orientada hacia el mercado internacional, el regreso al libre cambio y las ventajas relativas (DE RIZ; TORRE, 2002). De modo progresivo, la "reforma" fue sustituida por "transformación agraria", sutilezas del lenguaje que condensaban cambios de prioridades. Las propuestas más moderadas caracterizaron la toma de decisiones, en tanto la preocupación por el "estancamiento" (BALSA, 2006, p. 160) productivo y la situación de los sectores no propietarios rurales, marcó el rumbo de las discusiones. En este marco, atravesado por conflictos con la cuestión de los arrendamientos rurales, la colonización agrícola no tuvo un lugar predominante, una muestra de los significativos vaivenes de la política.

Durante el período que abrió el desarrollismo en el país, se produjeron discursos y prácticas desencontradas en torno de la cuestión colonizadora. En los inicios Arturo Frondizi (1958-1962) enfatizó la importancia de producir cambios en la estructura propietaria, aunque esas nociones se fueron licuando. Posteriormente se enfatizó sobre el aumento de la productividad mediante la incorporación de capitales y tecnología, mientras iban perdiendo espacio, aspectos que pudieran descontentar sectores concentrados del poder agropecuario. Su correlato en la provincia de Buenos Aires, a cargo de Oscar Alende, imprimió un curso más alentador para la creación de colonias, aunque finalmente fue limitado por las circunstancias sumamente inestables que proveía el panorama nacional (LÁZZARO, 2008).

Los años que siguieron se caracterizaron por una serie de prórrogas al vencimiento de contratos de arriendo, una medida heredada que también denotaba la intención de contener la situación de los productores sin quitar garantías a los propietarios. En esta 
La etapa que se inició con la presidencia de Arturo Illia (1964-1966) se orientó al desarrollo de una política económica global, mientras el interés se ponía en el sector externo (RAPOPORT, 2005; LÁZZARO, 2002-2003). Pero el campo no quedó totalmente desvinculado en tanto los objetivos propuestos sólo eran realizables si se fomentaba un “impulso armónico de la producción en el agro y la industria” (ARGENTINA, 1963). La armonía a la que aludía se fundaría en una aceleración de la productividad rural, para lo cual sería necesario mejorar el nivel tecnológico. Pero también aludía a la necesidad de modificar el régimen de propiedad de la tierra para facilitar el acceso por parte de los auténticos productores que, en palabras del presidente, gozarían "de una adecuada ayuda crediticia que asegure este objetivo" (ARGENTINA, 1963). Aun así, la política colonizadora se desvanecería en un espiral de avances limitados y retrocesos intencionados derivados de un panorama interferido por permanentes rupturas institucionales.

En este marco la colonización desarrollada cerca de las ciudades, aunque en la retórica fue particularizada, reveló rasgos dispersos. Tal vez por las propias discontinuidades de la política general, no se estructuró como una vertiente distinguida de aquella ejecutada en espacios más tradicionalmente rurales. Aun así se registran casos que integraron esta línea. En la provincia de Buenos Aires, se pueden indicar, además de las dos colonias aquí trabajadas, "Sarandí" (Avellaneda), "Los Porteños", "Santa Mónica”, “Las Banderitas” (La Plata) y "Laguna de los padres” (Mar del Plata), entre otras. En este escenario complejo quedaron ancladas experiencias, decisiones y transformaciones en las vidas de múltiples familias vinculadas a los programas oficiales de colonización, donde experimentaron tanto el auge como la decadencia de esta particular política. 


\section{Algunas notas sobre famílias y memorias}

Con el objetivo de avanzar en el estudio resulta indispensable conceptualizar la vida familiar, a partir de una consabida diversidad que parece ser su norma universal (COLLIER; ROSALDO; YANAGIZAKO, 1992). Resulta evidente la complejidad de una tarea que ocupó numerosas páginas en virtud de los diversos rasgos pueden ser considerados más allá de los habitacionales y vinculares, como los criterios más aludidos.

En ese sentido, ante la multiplicidad se considera sugerente la definición de Perrot (1990, p. 131 apud HAREVEN, 1995, p. 135) quien considera que "la familia se describe a sí misma, piensa en sí misma y se presenta como una unidad sostenida por un flujo continuo de sangre, dinero, sentimientos, secretos y memorias".

Pero si la familia es un "flujo continuo de sangre", no por eso es una amalgama de individuos. Por el contrario, se trata de una organización social compuesta por relaciones de producción, reproducción y distribución en la que intervienen aspectos vinculados con el poder, la ideología y el afecto (JELIN, 1998). Así, se pone en evidencia su latente conflictividad. Desde esta perspectiva, si bien la familia se perfila como un sujeto con agencia también desvela intereses contrapuestos que emergen en la superficie de la vida doméstica y se vinculan con la toma de decisiones.

La intervención de Bourdieu (1994) contribuye a aclarar este doble carácter. La familia es tanto una categoría social objetiva (estructura estructurante) como social subjetiva (estructura estructurada). Al mismo tiempo es una categoría mental que comporta múltiples representaciones que contribuyen en su reproducción como condición objetiva en las arenas donde se dirime el orden social. La reproducción biológica es su dominio, pero también la social, donde se constituyen espacios y relaciones.

Este carácter socio-simbólico también revela que las familias son cuerpos y campos a la vez. Son campos en el momento en que se asumen las decisiones en el ámbito doméstico entre miembros que tienen roles con diferentes cuotas de participación y voces más o menos autorizadas. Pero también pueden funcionar sumando esfuerzos individuales en torno de un propósito común. Esta perspectiva matiza la "pasividad" de la 
familia al traslucir diferentes modalidades de participación entre los miembros, al tiempo que propone una visión sobre la jerarquización de los vínculos familiares que involucra el género (BOURDIEU, 1994).

Dicho lo anterior, el ámbito doméstico puede definirse como:

las actividades de producción y consumo cotidiano de alimentos y otros bienes y servicios de subsistencia, así como las actividades ligadas a la reposición generacional, es decir, tener hijos, cuidarlos y socializarlos. (JELIN, 1984, p. 10).

Pero sus efectos no solo son materiales, sino también afectivos "de refuerzo, recreación, ruptura y autonomización de lazos y relaciones sociales, y una dimensión simbólica ligada a valores e ideologías propias de cada clase o sector social” (JELIN, 1984, p. 34). No obstante, dividir de forma taxativa entre lo productivo y reproductivo en un ámbito de rasgos rurales -en el que ambas esferas se encuentran bien entrelazadassupone un avance cauteloso. 4

Ahora bien, la reconstrucción de la familia rural a partir de la memoria requiere de ciertas consideraciones. Se debe tener presente que la memoria familiar tiene tres funciones. La primera está relacionada con reproducir un legado e internalizar un “nosotros" en cada individuo (transmisión). La segunda ubica en escena recuerdos de la infancia y la vida en familia en vinculación con los sentidos (reviviscencia). En tanto que la tercera incorpora experiencias previas como aprendizajes al entramar retrospección con proyección a futuro (autoevaluación). En ese sentido, la memoria familiar es un hilo conductor intergeneracional que consolidando un "nosotros" (MUXEL, 1996, p. 13-15) presente y restituyéndolo en el pasado. ${ }^{5}$ Representa también un modo de obtener lecciones de la experiencia familiar, de llevar una mirada distanciada respecto de lo sucedido, las circunstancias y los personajes. Lejos de ser una mera repetición, es un permanente circuito de negociaciones y renegociaciones (MUXEL, 1996).

\footnotetext{
4 Para profundizar en las conceptualizaciones posibles con referencia a la familia rural se sugiere la lectura de PARDÍAS, Silvina. Perspectivas sobre el trabajo en familias tamberas entrerrianas: aportes para una revisión conceptual. In: $2^{\circ}$ JORNADAS DE INVESTIGADORES EN FORMACIÓN, IDES, 2012. Actas de [...] Buenos Aires. Eje: La problemática del trabajo en el diálogo interdisciplinario: abordajes y perspectivas. Disponible en: https://www.aacademica.org/silvina.pardias/7.pdf

${ }^{5}$ Traducción realizada por la Dra. Talía Gutiérrez del texto original en francés.
} 
La memoria también posee una dimensión espacial en la medida en que en las experiencias del pasado resuenan la vida familiar. Lo comunitario anida en ella, integrando experiencias vitales a través de los vínculos trazados entre sus miembros (NORA, 1984; SEGALEN, 2008). De igual manera, la identidad de los individuos se reconoce por los lugares a los cuales se hace referencia, de modo que se representa una geografía de los espacios familiares e infantiles (MUXEL, 1996). Por eso el testimonio de la propia infancia puede despertar reflexiones acerca de su propia agencia, pero también como "caja de resonancia” de estructuras sociales y familiares pretéritas (CARLI, 2011).

Lo anterior es valioso porque los testimonios recogidos pertenecen a los miembros más jóvenes de las colonias por cuestiones relativas al ciclo vital. De hecho, la mayoría de las entrevistas corresponden a personas que llegaron en las etapas fundacionales (definidas entre 1951-1955) cuando cursaban los límites de la etapa escolar. De este modo los hechos registrados están empapados de perspectivas infantiles e impresiones que los sujetos incorporaban de sus propias familias. ${ }^{6}$ Otro grupo de entrevistas más reducido se realizó a personas que llegaron más tarde, en una etapa de consolidación de las colonias (década de 1960) cuando tenían también esta franja etaria. Vale considerar entonces que aunque se trate de un estudio anclado en dos temporalidades diferentes se trata de etapas de crecimiento productivo, mientras cursaban una fase expansiva, de reproducción (ARCHETTI; STOLEN, 1975). El modo en que se planteaba sus derroteros, sus vidas cotidianas en relación al aspecto productivo o a la domesticidad serán los temas de los que nos ocuparemos a continuación

\section{Familias colonas, entre representaciones y políticas}

La política de colonización, fundada en nociones tradicionales sobre la importancia social, económica y simbólica del campo, también dialogaba con representaciones sobre la familia como núcleo básico de la sociedad. En ese clima de ideas la familia rural cubría un espacio singular al ser vinculada con aspectos productivos ensalzados, mientras que

\footnotetext{
${ }^{6}$ Para profundizar sobre estas cuestiones se sugiere la consulta de De Marco, 2018a y 2018b.
} 
debía asegurar su permanencia en el campo. En este punto las propuestas en espacios periurbanos suponían ventajas evidentes porque lograr la radicación familiar era entendido como una cuestión de incentivos. Por eso, en alusión a los problemas más frecuentes de adaptación, expertos opinaban que de realizarse cerca de la ciudad todos esos inconvenientes desaparecerían. Se condensaban así varias ideas gravitantes en la época sobre las condiciones fundamentales para el éxito de la empresa colonizadora en espacios cercanos a las ciudades: familias numerosas, aclimatación progresiva, paciencia y expectativas moderadas por parte del agricultor (TENEMBAUM, 1946). Vale la pena prestar atención al modo en que se articulaban las ideas. Aunque la colonización se dirigía primordialmente al "elemento nacional", las familias inmigrantes formaban parte del panorama. A través de un proceso de selección y encauzamiento (BIERNAT, 2007) eran valoradas aquellas que tuvieran aptitudes para la producción rural (ARGENTINA, 1953). Por eso, en lo que respecta a las propuestas colonizadoras del peronismo -en su vertiente nacional o en la provincia de Buenos Aires-destilaba una idealización del sujeto familiar rural a partir del perfilamiento de los destinatarios.

En efecto, las entidades colonizadoras recurrían a un rígido sistema de evaluación para elegir postulantes. Los más considerados eran los productores agrarios mayores de edad con experiencia, o bien técnicos agrónomos para acompañar y capacitar a productores. También importaba si el colono era argentino (10 puntos), extranjero con residencia ( 8 puntos) o si tenía domicilio en la región (10 puntos). Especialmente se valoraba si era egresado de un establecimiento con orientación agrícola (30 puntos), junto con aspectos morales evaluados a través de buenas referencias y ausencia de antecedentes penales. Los postulantes no debían poseer unidades económicas, como tampoco su cónyuge, ni presentar defectos físicos o enfermedades crónicas. También se contemplaba que contaran con herramientas y participaran activamente en cooperativas (ARGENTINA, 1954, p. 8, arts. 29-30). En efecto, las entidades colonizadoras recurrían a un sistema de evaluación para elegir postulantes. 
Sin embargo, el perfil de los solicitantes sólo quedaba completo con la configuración familiar, prefiriéndose núcleos numerosos de origen argentino. Una tabla de puntaje establecía que el recorte etario más valorado para el adjudicatario era de 26 a 45 años. Los matrimonios aventajaban en 10 puntos a los solteros, incluso si estos contaban con hermanos, tíos u otros parientes adultos que pudieran colaborar en la producción. Los hijos constituían un elemento decisorio, aunque su aporte estaba marcado por las diferencias por género. Los varones de 14 a 20 años eran los que más beneficiaban en la presentación (5 puntos), mientras que las mujeres si tenían más de 18 años aportaban algo más (3 puntos) que los menores de 11 años, sin distinción de sexo (1 punto).

De cara al análisis de las familias rurales las fuentes constituyen un desafío. No se encontraron documentos del IAC o del BNA/CAN que presenten datos sobre las condiciones de las familias una vez instaladas en los lotes. Inexistentes o perdidos, resultó difícil reconstruir la mirada tutelar del Estado acerca de los sujetos depositados en las tierras, ni siquiera en lo referente a su desempeño productivo. Los escasos datos producidos por instituciones oficiales apenas conforman unas briznas del multiforme tejido familiar de las colonias.

No obstante, se dio con algunas pistas. Los datos aportados por los fragmentarios rastros documentales fueron complementados con una minuciosa reconstrucción que sugería que no siempre primó el peso de la letra. Si bien los núcleos familiares de las colonias analizadas eran numerosos, se constató una inmensa mayoría de familias inmigrantes entre las que predominaban japoneses e italianos, aunque el abanico de nacionalidades era amplio (DE MARCO, 2018a).

En ese sentido resultó valioso el hallazgo de un informe elaborado por el Comité Intergubernamental para las Migraciones Europeas (CIME) en 1957 sobre familias italianas ingresadas vía convenio internacional en las colonias estudiadas. Incluso cuando el documento sólo abordaba una parte del universo familiar, resulta iluminador. En colonia “La Capilla” se apuntaban dificultades adaptativas y económicas derivadas de la falta de un capital inicial. Aunque se rescataba la tenacidad de las familias, poco se decía sobre la forma en que se organizaban para producir y cómo vivían. Con relación a la colonia 
“Urquiza” los problemas del sistema de riego y del agua para consumo hogareño eran centrales. La evaluación traslucía que "la solvencia económica del migrante, la organización del transporte y comercialización de los productos" (CIME, 1954) eran en ambos casos problemas urgentes.

Es posible que lo más interesante del citado documento sea el compendio de fotografías que complementaban los informes y que dan cuenta de la organización de los espacios domésticos y extra-domésticos, tanto como de escenas de trabajo rutinarias. Incluso cuando un aura de artificio enreda algunas capturas, surgen otras que evidencian la vida familiar subyacente.

Las escenas de trabajo son protagonizadas por hombres jóvenes que trabajan la tierra, conducen arados y montan caballos entre calles de tierra que delimitan los lotes. Por esos mismos caminos también pueden verse niños que regresan de la escuela. Las niñas son fotografiadas en tareas domésticas exteriores, o bien mirando con curiosidad las labores que los hombres ejecutan en espacios donde el hogar limita difusamente con las producciones. No se divisan mujeres, ni afuera ni adentro de las casas. Sólo integran las fotografías en las que aparece el conjunto familiar en su rol de esposas de los colonos.

Resulta evidente que esta miope mirada institucional patentiza como los exteriores que son la "esencia" de las colonias, en tanto que poco se ve del interior de las casas. Algunas fotografías muestran un dormitorio sencillo pero pulcro, ordenado, con muebles de madera lustrada, espejos y pocos ornamentos. La cocina, más bien pequeña, aunque esmeradamente limpia, cuenta con horno y aparadores. Por último, se muestran los exteriores de las casas terminadas, algunas de ellas con ladrillos a la vista. Con la familia delante de los frentes pintados se puede ver a los miembros visiblemente engalanados para la ocasión, o con ropa de trabajo y guardapolvos escolares. Se trata de escenificaciones del hogar rural que desvelan frugalidad, sencillez, pulcritud y sacrificios acompañados por estereotipados roles de género que se adecúan a las representaciones sociales dominantes que circulaban desde décadas previas. 
Imagen 1. Hombres trabajando la tierra con caballos en "Colonia Urquiza”, 1957

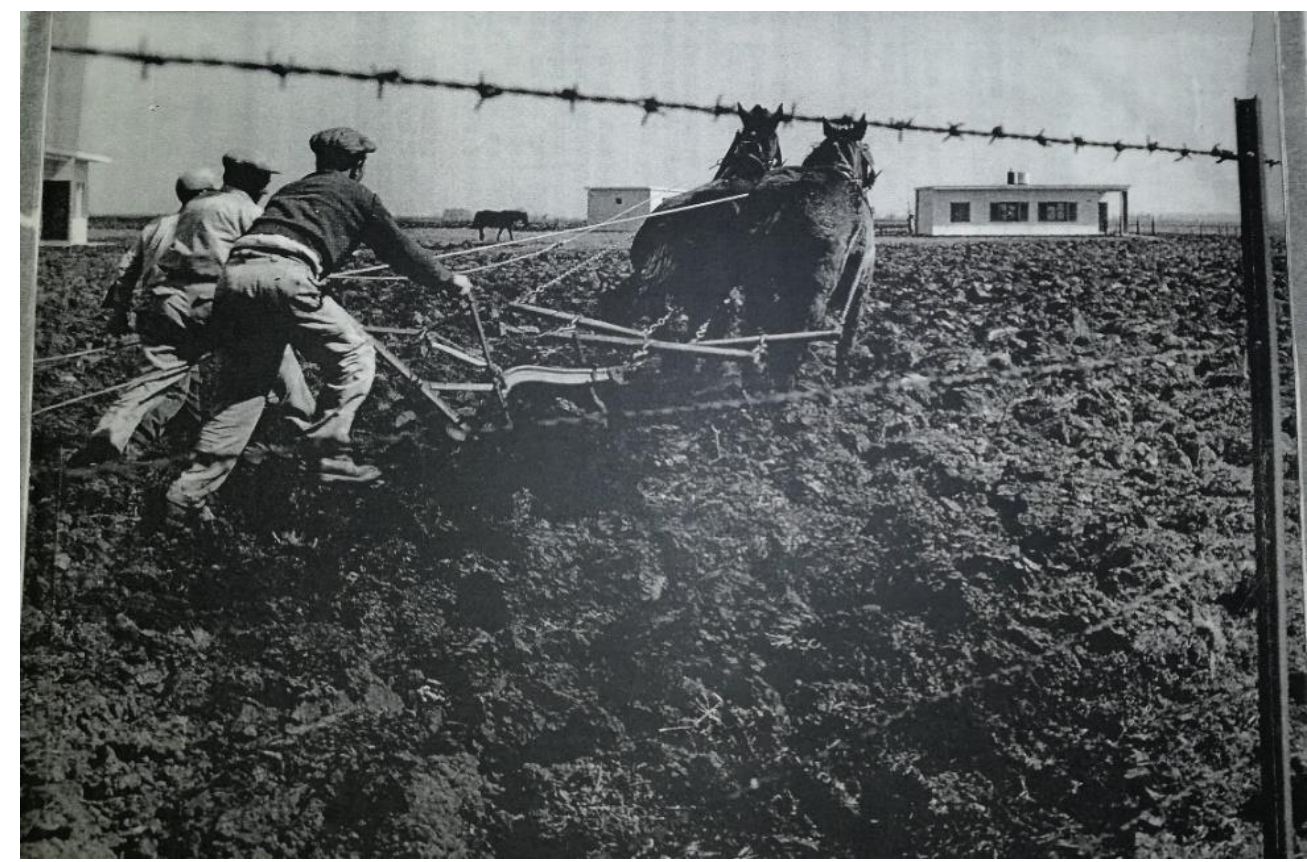

Fuente: CIME. “Colonización Agrícola en Argentina. Planta Piloto Escuela Santa Catalina”, 1957. Fasc.3666, p. 9. IAO. CDI.

Imagen 2. Familia italiana (no identificada), “Colonia La Capilla”, 1957

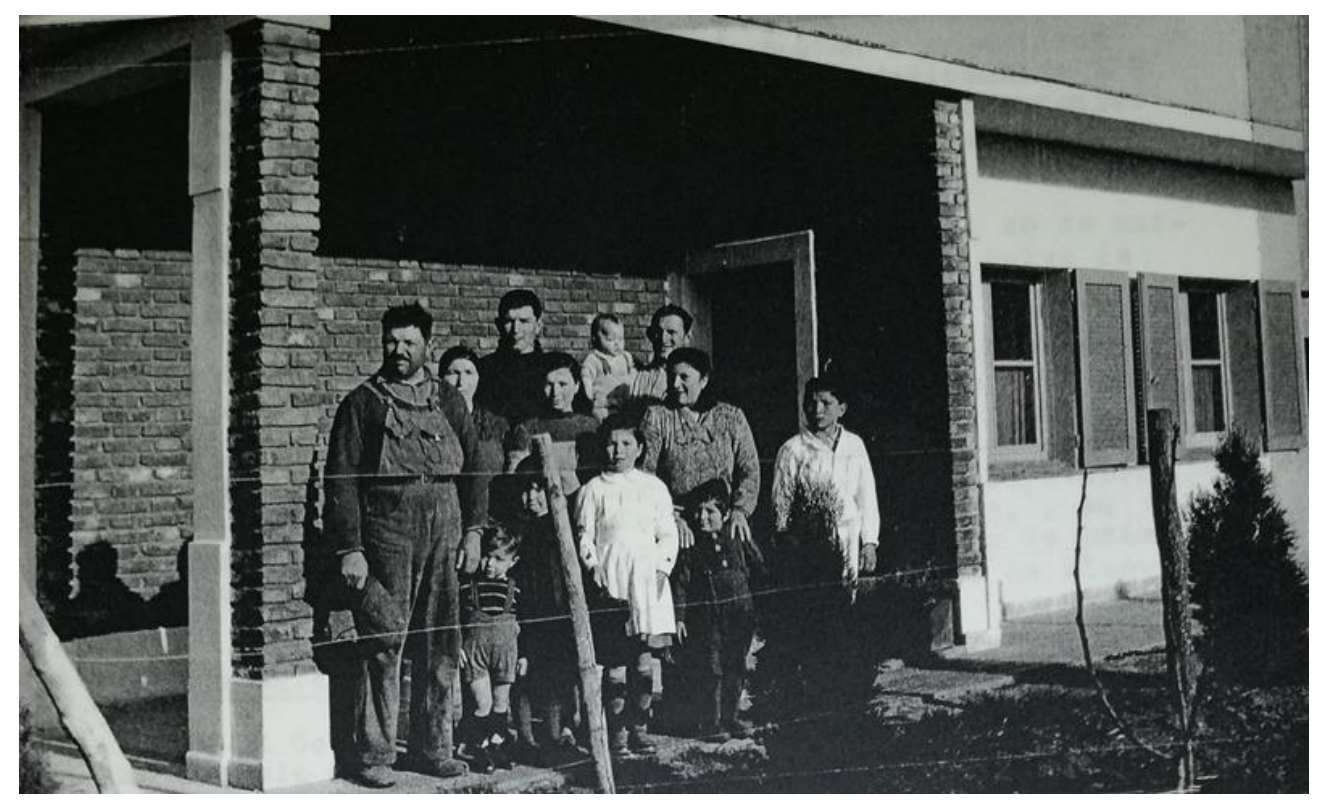

Fuente: CIME. "Colonización Agrícola en Argentina. Planta Piloto Escuela Santa Catalina”, 1957. Fasc.3666, p. 13. IAO. CDI.

La escasa recuperación a través de los ojos del Estado se complementa con la indagación que la prensa nacional y local realizó en hogares de este tipo de emprendimientos. Las notas periodísticas fueron escritas en general con la finalidad de 
colonia “La Capilla” donde “desde los abuelos hasta los más jóvenes de las familias japonesas, todos ellos, trabajaban de sol a sol en la producción florícola” (NOTAS..., 1957, p. 16). Algunas fotografías que acompañaban este tipo de notas en periódicos locales también mostraban al grupo familiar completo en una fusión de realismo con ficción: escenas de labor cotidianas en las cuales los miembros de la familia lucían sus mejores prendas.

En ese sentido, en 1964 el diario El Día de La Plata titulaba “Fe, esperanza y ¡un tractor!" a una nota que denunciaba la necesidad de implementos agrícolas con base en una serie de entrevistas a colonos de distintos orígenes en colonia "Urquiza”. Una mirada a los problemas cotidianos incluía un paseo por los hogares. Las casas se advertían limpias y equipadas con gas de garrafa. Las familias devolvían un cuadro en que cada uno ocupaba su lugar. Llamaban la atención las mujeres "jóvenes y bellas” que hacían -con una imagen de cocina como testimonio- "más llevadero el magro destino [en el] surco, bajo el cual los hombres parecen prosternarse". Los hombres y nadie más que ellos. La nota, además, aparecía coloreada con la reconstrucción de un día típico que devolvía roles y tareas idealizados:

La vida en la quinta comienza a las 5 de la mañana. Se levanta el horticultor, junto con los suyos, $y$, antes del alba, ya está en la cocina escuchando el ladrar de los perros y el sonidillo murmurante del rocío que baja por el tejado. No bien clarea, su andar se dirige al surco. Allá le esperan sus caballos, la tierra húmeda, la cerrazón ambarina, que se abre como el surco mismo y tiene la caprichosa voluptuosidad de las esperanzas desmedidas. Al salir el sol el trabajo está avanzado. Hay que preparar cañas para el tomate, pues la temporada se viene encima, y también hay que recoger otras hortalizas, aprovechando el fresco del amanecer. Desde la cocina sale un humo suave y llega hasta el campo un olor penetrante que recuerda a todos que, dentro algunas horas, habrá un descanso reparador y buena comida para el almuerzo (FE..., s/d, 1964) 
Un año más tarde sería otra comunidad, minoritaria y tardía, la que atraería la atención de la prensa local. Con una nota que explicaba la angustiosa situación de los españoles que habían ingresado a colonia "Urquiza" con el buen visto del CIME y bajo la égida del Centro de Movilidad de Mano de Obra, se expresaba que luego de la discreta visita de un ingeniero que les proporcionó herramientas, las familias denunciaban falta de acompañamiento estatal (ESPAÑOLES..., s/d, 1965). Reclamos y sacrificios convivían en las páginas de los periódicos que, sin embargo, pocas veces brindaban espacio a las familias rurales de las colonias.

Resulta claro que las miradas sobre la vida cotidiana en los lotes, tanto las institucionales como las de la prensa, ocultaban más de lo que pueden mostrar en varios sentidos. A partir de lecturas en ocasiones benevolentes, la vida doméstica quedaba en esencia subsumida en las labores productivas. No se revelaban siquiera matices o dimensiones conflictivas, al tiempo que la dimensión individual quedaba desdibujada. Otros trazos devuelven, en cambio, la rememoración por parte de los protagonistas.

\section{Reconstrucción de la vida familiar desde el recuerdo}

En contraste con los documentos oficiales institucionales o notas de prensa, las entrevistas semiestructuradas se perfilaron como fuentes ricas a través de las cuales distinguir cómo los sujetos reconstruyen desde su recuerdos y memoria familiar una vida hogareña, ya no modelada para el ojo de la cámara periodística ni mejorada para la mirada institucional, pero sí interpretada para quien pregunta. Incluso cuando algunos testimonios pretendían minimizar las vivencias negativas de la colonización en el seno familiar, 7 afloraron múltiples experiencias en los resquicios de la cacofonía de voces relevadas. En este sentido resulta interesante reconstruir el día a día familiar con el

\footnotetext{
7 Las causas de esta actitud son múltiples. En ocasiones parece responder a un convencimiento genuino de que el pasado fue mejor, más sano, esforzado pero muy honrado a tono con representaciones vinculadas a la vida familiar en el campo. La "gratitud" que expresan hacia sus progenitores, y en ocasiones, hacia el mismo Estado argentino, se traslada hacia una valoración positiva de todos los aspectos. En otras oportunidades parece dominar la necesidad de ser "políticamente correcto" con el entrevistador, y a los diferentes grados de rapport logrados. Pero a veces estas miradas fueron dando paso a observaciones puntuales que revelaban críticas y disgusto (cuando no eran abiertamente negativas), desvelando interesantes matices de la vida hogareña.
} 


\subsection{Ingreso y producciones}

Lejos de ser excepciones, las referencias sobre los inicios en las colonias coinciden en que el primer desafío de muchos fue hacer de esas tierras áridas un hogar. Algunos esbozan imágenes potentes a partir de referencias sobre el frío y la vacuidad del espacio. Una mujer que tenía 13 años al llegar a "La Capilla" afirma que todo "era cardo, alambre y nada más" (SUJETO 1, 2014. Información oral). Sus memorias, como tantas otras, ilustran experiencias tripartitas que las primeras familias atravesaron al llegar: edificar casas, preparar terrenos, plantar árboles de sombra, tareas que se hacían en simultáneo. Las valoraciones de mujeres y varones no mezquinan en adjetivaciones o comparaciones mediadas por metáforas que remiten al frío, la soledad y la nada, lugares comunes que se replican para describir la génesis de los emprendimientos. La excepción a estas apreciaciones pertenece a aquellos italianos que al llegar encontraban casas a estrenar como acuerdo en el marco de un convenio que los involucraba (DE MARCO, 2015). Pero constituyen la excepción.

En efecto, para los italianos del convenio la situación era distinta: "nos dieron un lote, la casa, me prestaron plata también para comprar caballos, para vivir, para todo", explica Domingo, que llegó a "La Capilla" en 1954. Sus problemas eran de otro orden: “empezamos fácil, no era que era tan difícil, el problema era la estación [del año]" (SUJETO 2, 2015. Información oral), y admite que a algunas familias les costó más. Su esposa, que vivía en un lote contiguo y vino en las mismas condiciones, acepta y redobla: “Los primeros tiempos era difícil. A nosotros sí nos costó [...], perseverar era un triunfo" (SUJETO 3, 2015. Información oral). Los primeros eran quinteros desde que podían recordar, los segundos habían vivido toda su vida en el pueblo. Esta diferencia bifurcaba sus experiencias, como sucedía con muchos otros colonos. Los espacios abiertos, las distancias entre las casas, más el silencio, la lluvia y el barro eran cuestiones que afectaban el día a día en el nuevo espacio, mucho más ajenas para los que estaban habituados al movimiento urbano, incluso desde un remoto pueblo en Italia. 
Este tipo de lecturas no responden exclusivamente a los primeros tiempos, porque con el paso de los años muchas de las carencias de la época fundacional no fueron solucionadas. De hecho, en 1962 el arribo al lote dejó en María -hija de ucranianos que en aquel entonces rondaba los 15 años- las más negativas impresiones: "Me enojé cuando vi tanta desolación... ¡venir acá era estar en un estado salvaje!, había que buscar la leña para cocinar, no había nada" (SUJETO 4, 2015. Información oral).

Los comienzos en "Colonia Urquiza” cuando promediaba la década de 1950 fueron un poco más parejos en principio porque sus primeros habitantes, un puñado de familias italianas cuyos inicios fueron facilitados por el convenio antes referido. Si bien es cierto que sus ingresos se demoraron porque las viviendas no estaban terminadas en el tiempo previsto, los colonos tenían iguales facilidades en ese sentido incluso cuando en lo productivo las dificultades fueran varias. Pero distinto fue el caso de las familias japonesas que comenzaron a llegar en la década de 1960.

En ese sentido, un floricultor nipón recuerda: "tuvimos que construirlo todo", en un ambiente en el que -como confirma su hija- "era todo campo, no había asfalto, era todo tranqueras, era todo pasto alto, no había nada" (SUJETO 5, 2015. Información oral). El todo de la colonia era la nada. Mientras que sus vecinos italianos tenían las cuestiones habitacionales resueltas, ellos junto con otras familias aún en la década siguiente tenían una casa con techo de chapa y un pozo en lugar de un cuarto de baño de material. Es cierto que algunos de los primeros japoneses se vieron inesperadamente beneficiados al recibir casas de material que habían sido hechas para familias peninsulares que nunca llegaron, (SUJETO 6, 2015. Información oral) pero fueron los menos. Aun así, hacia 1963 la colonia aún era percibida como "una zona muy desértica, puro campo, sólo la casa" (SUJETO 7, 2015. Información oral).

En general la edificación del hogar colono no fue una tarea sencilla. Para la gran mayoría los tiempos de entrega, las condiciones de los terrenos y las prioridades no siempre iban de la mano. A lo anterior se agregaba que la construcción de las casas no era sólo una necesidad obvia, sino un requerimiento de las entidades colonizadoras que no dejaban de exigir cada vez que enviaban inspectores. Es cierto que con esos fines se podía solicitar un préstamo, aunque no todos podían acceder: “¿Quién te iba a salir de 
garante, si los que estábamos ahí no teníamos escritura? No tenías parientes, no tenías amigos. O tenías, pero con las mismas condiciones que nosotros" (SUJETO 8, 2014. Información oral). La solidaridad de los vecinos no siempre era suficiente para resolver los problemas que se presentaban.

Las memorias vinculan la radicación de las familias también con otros desafíos relacionados con situaciones imponderables, pues las colonias, aunque eran espacios prometedores, también eran propicias a heladas, viento y granizo que destrozaban cultivos. Tal vez esto no tomó por sorpresa a los que eran conocedores de la zona (o de otras similares) pero para muchas familias inmigrantes fue un amargo descubrimiento. La salida más lógica era construir invernaderos, a su vez más rentables, pero si bien protegían de ciertos males, los más antiguos (de vidrio) no siempre resistían las tormentas que volaban techos y destrozaban galpones dejando sembradas de chapas y vidrios las flores y verduras. Como muestra alcanza con mencionar una colosal tormenta ocurrida en 1955 en “La Capilla”, recordada como un verdadero “tornado" que recorrió lotes barriendo edificaciones precarias a su paso (SUJETO 9, 2015. Información oral). Por supuesto estas situaciones eran golpes anímicos, pero sobre todo económicos que complejizaban el día a día en las tierras.

Una vez más se vislumbran distintos puntos de partida entre familias que ponían en juego sus recursos frente a diferentes carencias. Esto en el contexto de un Estado que otorgaba oportunidades de forma desigual en un mismo escenario, dejando fuera de ciertas facilidades a un importante sector poblacional. En ese sentido, Carlos, argentino de origen japonés, explica que en los inicios su familia dormía en un camión con acoplado en colonia "La Capilla". Recuerda que cuando supieron que habría inspecciones ministeriales para verificar las casas "apurados compraron ladrillos y [su] hermano los apiló y les puso la chapa. Así y todo, se hizo la perforación para el agua, después de a poquito se fue construyendo para vivir" (SUJETO 10, 2015. Información oral) ${ }^{8}$ Las condiciones de instalación iniciales eran a todas luces precarias y avanzaban con lentitud, con base en el esfuerzo diario.

\footnotetext{
${ }^{8}$ SUJETO 10. [Entrevista cedida a] Celeste De Marco, Florencio Varela (Buenos Aires), 25 feb. 2015
} 
Muchas veces la premura económica en que estaban sumidos implicaba que se iniciaran tareas productivas de forma simultánea con otras, como la edificación del hogar. Por eso las primeras cosechas se destinaban al consumo familiar y enseguida intentaban obtener cultivos sencillos y rendidores para sustentarse sin generar muchos gastos en una etapa en la que las inversiones se iban realizando junto con la formación del capital, pues no eran frecuentes los ahorros previos. Este tipo de situaciones eran comunes e identificadas como problemas en documentos institucionales que daban cuenta de un sujeto familiar con carencias que si no se superaban podían amenazar de ruina el arraigo.

Lo mismo sucedía con el abastecimiento del agua para consumo y producciones. Los primeros motores a los que podían acceder eran verdaderos quebraderos de cabeza con limitaciones que requerían de paciencia e ingenio pues encenderlos podía llevar dos horas y el trabajo de cinco o seis personas (SUJETO 8, 2014. Información oral). Una medida de kerosene y una aplicación precisa de fuerza eran la diferencia entre el encendido de la máquina o la recepción de un golpe (o "patada"). Por supuesto no todas las familias disponían de tantos brazos, por lo que debían recurrir a vecinos. En este sentido las condiciones de las colonias indicaron diferentes respuestas. Mientras en colonia “La Capilla" se constató la formación espontánea de un sistema de solidaridad en diferentes espacios colectivos, en colonia "Urquiza" estas manifestaciones estaban atravesadas por diferentes fechas de ingreso y dirigidas principalmente al interior de las comunidades étnicas, incluso cuando la cordialidad permeaba el trato entre las familias.

Es importante señalar que en los inicios tuvo lugar un período de ensayos en el orden productivo para determinar en qué se especializarían las familias. Al principio muchos horticultores probaron suerte con "cosas más fáciles" (rabanitos, puerros, verdeo) (SUJETO 2, 2015. Información oral). Para aquellos con experiencia esta etapa fue rápida; pero para otros fue un proceso más engorroso:

Nosotros no sabíamos mucho de quinta cuando empezamos. Vino mi cuñado, de allá de Médanos y sacó de las plantas todo el tomate para mandarlos a Brasil. Se los mandaron de vuelta porque estaban chiquitos, no habían crecido, no habían madurado (SUJETO 11, 2015. Información oral) 
Finalmente, entre varios intentos muchos horticultores encontraron un remanso en las verduras de hoja y otros optaron por tener cultivos surtidos en el lote, más allá de la temporada, una estrategia para salvaguardarse cuando las producciones de estación habían pasado (SUJETO 8, 2014. Información oral; SUJETO 12, 2014. Información oral; SUJETO 13, 2015. Información oral).

Con referencia a lo anterior, aunque las entidades colonizadoras requerían la producción de hortalizas muchos se abocaron a las flores. La aplicación de esta exigencia en colonia "La Capilla” fue más bien tolerante, lo que dialogaba también con una menor intromisión de la institución. Pero en colonia "Urquiza" la situación era otra. Un productor florícola japonés expresa que para acceder al terreno debían "ser agricultores, no floricultores", pero como tenía que pagar mensualmente el lote y con las verduras no podía, cambió de idea. Aunque sabía que era un plan audaz: la normativa exigía que al menos el $40 \%$ del lote tuviera verduras y sabía que al llegar los inspectores "si veían que hacía flores, se enojaban" (SUJETO 7, 2015. Información oral). Pero, incluso cuando no fueron pocas las veces que inspectores visitaron las tierras para confirmar su cumplimiento, los japoneses persistieron y lograron un notable desempeño en esta producción.

Más allá de los ensayos, las decisiones productivas tenían relación con una progresiva integración y la pertenencia a ciertos grupos. Para muchas familias se trataba de un derrotero de pruebas con costos monetarios y de tiempo que formaban parte de una etapa de acomodamiento a demandas del mercado, posibilidades propias y requerimientos institucionales que no siempre coincidían. Muchos pudieron sobrellevarlo, pero otros no. De esos aquí no se puede dar cuenta más que por los testimonios de quienes los vieron irse y escucharon (o supusieron) sus razones.

Para los japoneses de ambas colonias -pero posiblemente aún más para los de colonia "Urquiza"- la floricultura fue sopesada en colectivo. Como sugiere una entrevistada: “¿acá como aprendimos? mirando al vecino cómo pone los palos, el gajito” (SUJETO 4, 2015. Información oral). Esto implicaba un respaldo a las iniciativas, pero también una atenta mirada entre los connacionales que para algunos podía resultar 
correctiva y limitante. Pero además de decidir qué producir, existían otras cuestiones también complejas.

La comercialización en ambas colonias presentó dificultades. En colonia "La Capilla" primó una variedad de estrategias, pues muchos se valieron durante años de la tracción a sangre y esto suponía severas dificultades cuando el agua, el viento o la helada terminaban en caminos anegados. Como una estampa, Silvia recuerda que cuando era pequeña su padre iba siempre a vender las verduras del lote con el carro tirado por caballos (SUJETO 14, 2015. Información oral).

A veces entraba el camión cuando no llovía, pero cuando llovía había unos zanjones así y tenías que salir con la rastra, con los caballos, porque no teníamos tractor cuando recién nos casamos. El asfalto lo hicieron en los años '70, después de que me casé. En esa época helaba. Nevaba un día y [mi marido] llegó agarrotado a [la ruta de] La Capilla, con las manos las golpeaba y no las sentía. Pero llegaba, tomaba una copita de algo y seguía (SUJETO 15, 2015. Información oral)

La adquisición del vehículo propio era considerada un gran progreso porque facilitaba la producción. No es llamativo, entonces, que las fotografías de la compra del primer camión copasen álbumes de fotos familiares y fuesen exhibidas en algunas zonas comunes de las casas (ver Imagen 5).

Imagen 3. Camión de la familia Ceccini de la "Colonia La Capilla" con cajones vacíos después de haber descargado en el mercado, c. 1958-59

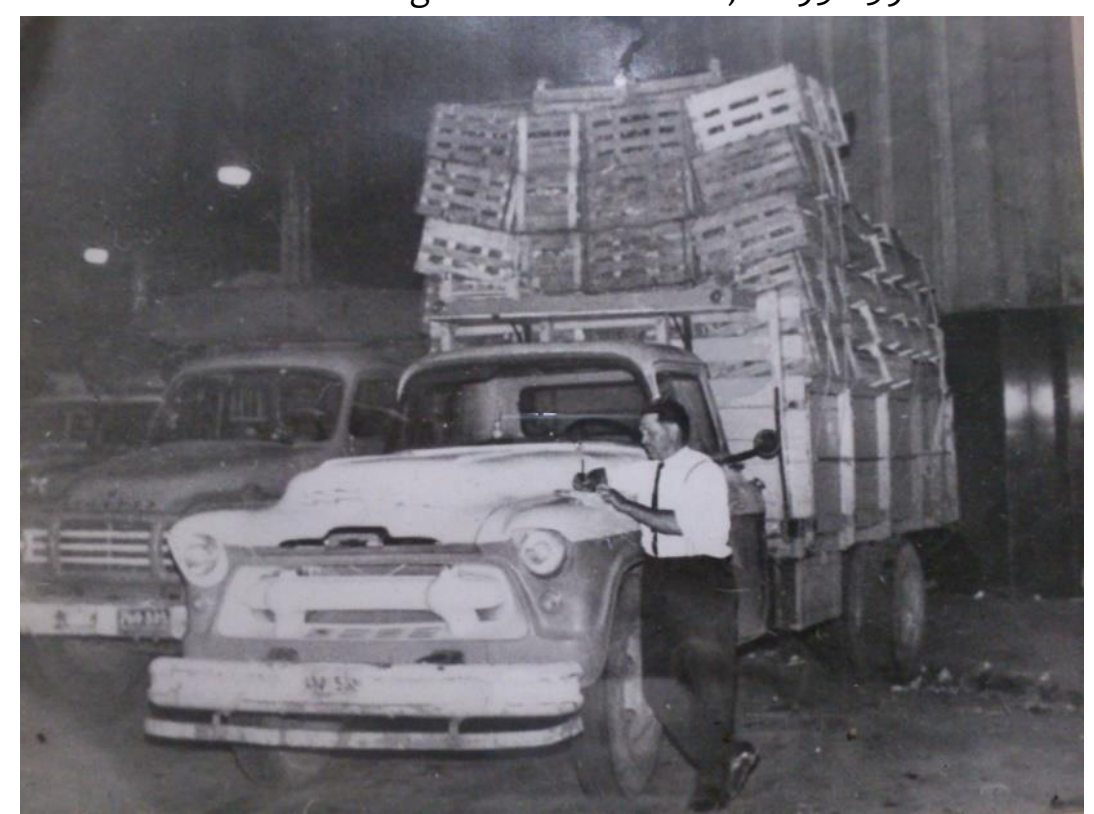

Fuente: Familia Ceccini, álbum familiar. Mercado hortiflorícola, circa 1955. 
Los modos de organizar la actividad comercial se relacionaban con el nivel de capitalización familiar, aunque la cuestión era bastante disímil. Algunas familias tuvieron problemas para invertir en un transporte propio, de hecho, algunos confiesan que nunca Ilegaron a tenerlo (SUJETO 16, 2015. Información oral). En esos casos optaban por recurrir a intermediarios que recogían las verduras de sus lotes, para llevarlas a puestos de venta y luego rendían el dinero a los colonos. Con dependencia de las épocas podían ir a los mercados de Abasto, Morón, Spinetto, Dorrego y/o Avellaneda, pagando por la carga, descarga y el descarte de sobrantes. El camionero que hacía de enlace era el que elegía el puesto también (SUJETO 2, 2015. Información oral). Este sistema estaba muy extendido pero era causa de amarguras por los recurrentes abusos: "Venia un vendedor que nos cobraba el 15\% de lo que vendía, y bueno, a veces te sacaba más cuando vos no estabas, te sacaba el 50\%" (SUJETO 17, 2014. Información oral).

En el caso de la colonia "Urquiza" la cuestión fue similar para las primeras familias y las que arribaron hacia mediados de los años '60, pero hubo diferencias para el contingente japonés. A mediados de 1970 la Agencia de Cooperación Internacional del Japón (AJLP) donó un camión para uso exclusivo de la colectividad (SUJETO 7, 2015. Información oral), de modo que no sólo prescindían de intermediarios sino que reservaban capital y fortalecían los lazos intercomunitarios. Por este motivo es evidente que la construcción de una colectividad sólida no sólo dependía del accionar de las familias, que ciertamente estaban muy involucradas, sino de voluntades institucionales que los trascendían.

Además, en colonia "Urquiza" los nipones colocaban sus producciones a través de una cooperativa de floricultores con sede en la capital federal. Los camiones llegaban ciertos días pautados, donde las familias aguardaban con canastos llenos para intercambiar por otros vacíos de la carga anterior. En el mercado central cada productor tenía un vendedor que informaba sobre la cantidad de paquetes vendidos y precios, para que luego los colonos retiraran en la cooperativa su liquidación (SUJETO 18, 2015. Información oral). Esto les daba poder de negociación frente a propuestas o exigencias de la cooperativa que otros productores no tenían por estar disgregados. En momentos 
de crisis intentaron diseñar estrategias conjuntas para evitar la competencia interna, aunque se afianzarían recién hacia 1990.

Es oportuno considerar que si bien este tipo de colonias tenían rasgos particulares por su ubicación (prestaciones, bienes y servicios accesibles), muchas de las problemáticas resaltadas en los testimonios permiten trazar un paralelismo con carencias experimentadas en otras colonias (previas y/o contemporáneas) fundadas en zonas netamente rurales. Este aspecto resulta cuando menos curioso si se tienen en cuenta los presupuestos de la colonización periurbana. En suma, el haber analizado estos aspectos con referencia a condiciones de radicación, modalidades de producción, potencialidades y dificultades según cada grupo y espacio conduce a plantear cómo era la organización familiar en torno al uso de la mano de obra en este esquema.

\subsection{Tareas femeninas y masculinas}

Como se ha apuntado, la propuesta colonizadora se fundaba en una organización productiva familiar intensiva, que en cuanto a espacios periurbanos cobraba aún más relevancia. Más allá de sus tornasoles, los testimonios indican que el uso de mano de obra familiar era lo más frecuente, aun cuando la contratación de peones no era una práctica aislada. ${ }^{9}$ Expresiones como "al trabajar en familia, los chicos, los grandes, los padres, todos trabajaban juntos" ilustran con frecuencia esa realidad (SUJETO 19, 2014. Información oral).

Así, al tiempo que iban superando una etapa inicial las familias se consolidaban también en el orden de lo doméstico. Pero en oposición a lecturas que ensalzaban el trabajo familiar conjunto a través de roles estáticos que sólo remarcaban las labores masculinas con rasgos propios, las entrevistas confirman que las producciones se estructuraban con el aporte también de mujeres y niños con cuotas de trabajo para nada secundarias. Los recuerdos colorean la vida familiar profundamente arraigada a la tierra, a

\footnotetext{
${ }^{9}$ En general se trataba de hombres adultos solteros de origen criollo o polaco que residían en el mismo lote familiar. Algunas vertientes de estudios de familia toman la cohabitación como un parámetro para delimitar el grupo familiar. Sin embargo, la imposibilidad de dar con estas personas y recuperar sus testimonios dificulta la reconstrucción de sus recorridos, modos de vida y prácticas, salvo a través de referencias puntuales de los ex colonos entrevistados.
} 
la propiedad y a la producción. Pero ¿cómo se imbricaba el aporte de los individuos con el esquema familiar? ¿Qué rol asumía cada uno de los miembros?

La organización de los trabajos era más bien porosa, y para profundizar en estos aspectos, resulta sugerente abordar las prácticas desde una perspectiva que contemple diferencias según género y edad, por lo que se propone enfatizar en la labor femenina. ${ }^{10}$ Una síntesis de las tareas cotidianas resulta un buen acercamiento a este universo. Con base en las entrevistas se reconstruyó un panorama de trabajos que la mayoría de las familias con independencia de su origen desempeñaban a diario, ya sea orientadas a la manutención de la familia y el hogar, como con relación a las producciones (ver Tabla 1).

Tabla 1. Actividades domésticas y extra-domésticas realizadas por las familias en las Colonias "La Capilla" y "Urquiza"

\section{Actividades intra-domésticas}

Compra de comestibles, ingredientes, elementos de cocina

Elaboración de alimentos (consumo inmediato o conservas)

Obtención de agua

Limpieza y mantenimiento general del hogar

Cuidado del huerto familiar o granja Compra, confección o arreglo de vestimenta/calzado Compra de utensilios escolares Cuidado de bebés, niños pequeños y/o familiares enfermos o ancianos

\section{Actividades extra-domésticas}

Siembra, cosecha y cuidado de cultivos y/o animales

Compra de insumos (herramientas, semillas) para la producción.

Manejo y utilización de maquinaria Pago de cuotas/aranceles de tierras o maquinarias

Conducción de vehículos propios Comercialización (mercados, abasto) Viajes a la ciudad

Fuente: Elaboración propia con base en entrevistas, 2018

\footnotetext{
${ }^{10}$ Vale la pena recordar cómo Stolen (2004) identificó las lógicas de la chacra y su funcionamiento en clave de género en la "Colonia Santa Cecilia" en Santa Fe. En ese sentido la autora señala diferentes modos de acceso a variables como la tierra, la tecnología y los ingresos, al tiempo que las tareas se bifurcan claramente entre mujeres y varones perfilando roles que se apegan a la dominación masculina.
} 
No obstante, para comprender la asignación de tareas y roles se debe remitir a las configuraciones familiares. La mayoría de los grupos domésticos en ambas colonias eran nucleares, conformados por un matrimonio y varios hijos, estructurados con base en una jefatura masculina desempeñada por el padre. ${ }^{11}$ Esto no descalificaba la importancia del hijo primogénito como mano derecha, quien usualmente tenía la autoridad de asignar tareas y consignar el tiempo que debían dedicarle a éstas los otros miembros.

En definitiva, el varón a cargo se ocupaba de organizar al cuerpo familiar en función de las necesidades. En líneas generales las familias se ajustaban a este modelo, salvo los japoneses de colonia "Urquiza” que presentaban una configuración más extensa por los agregados familiares cuyas funciones complejizaban el entramado.

Más allá de las diferencias había aspectos comunes que se visibilizaban en las tareas. Los varones desempeñaban varias actividades concretas: preparación de los terrenos; manejo de tractores, rastras y camionetas; siembra; instalación y encendido de motores para el riego; cuidado de cultivos; aplicación de abonos; control de plagas; cosecha; embalaje de flores o verduras; ordeñado de vacas en tambos, entre otras. Padres e hijos varones se abocaban a todas las tareas necesarias para obtener productos frescos de los campos, lo que incluía el trabajo in situ pero también el aprovisionamiento de elementos indispensables (semillas, herramientas, combustible) fuera de las colonias.

Lo anterior les valía una importante circulación e inversión de horas más allá de los lotes, en ciudades cercanas o incluso en la capital federal o provincial. Sin embargo, los varones no se encontraban solos ni concentraban en sí mismos todo del trabajo. Por el contrario, los testimonios revelan, en sus versos y anversos, que muchas de las funciones productivas que desempeñaban mujeres y niños eran centrales. ${ }^{12}$ Porque si en el orden de

\footnotetext{
${ }^{11}$ Una reconstrucción detallada sobre orígenes y extensión de los grupos domésticos, edades y géneros puede consultarse en De Marco, 2018a.

12 Stolen (2004) señala para la "Colonia Santa Cecilia” en Santa Fe que encuentra a las mujeres alejadas de las labores productivas y abocadas al universo doméstico, en el cual encuentran su razón de ser y las bases de su moralidad, individual y familiar.
} 
Esta es una distinción usualmente borrosa en ámbitos rurales, y los casos analizados no son la excepción de modo que la consideración hombre-producción y mujerreproducción adquiere matices. Esta tradicional división comporta una mirada que jerarquiza el mundo productivo y el espacio público como naturalmente masculinos, en tanto que endosa la vida doméstica al mundo femenino, y, en virtud de este carácter, lo desacredita. Pero lo doméstico, lejos de ser neutro e indiscutiblemente femenil, es un espacio en el que se contiende el poder y que trasciende la finalidad meramente reproductiva (JELIN, 1984).

En sus memorias como madres o esposas (o hijas que recuerdan a sus madres), las mujeres se encargaban desde temprano en la mañana de todos los menesteres del hogar y contaban con la colaboración de sus hijas. Juntas eran las encargadas de la alimentación y el cuidado, entre otras tareas intra-domésticas. Sin embargo, hasta qué punto el espacio doméstico podía ser objeto de reacomodamientos lo evidencia el hecho de que si estas ocupaciones colisionaban con intereses productivos estos últimos eran privilegiados. El lugar de la mujer idealmente era la casa, pero se podían encontrar alternativas para delegar funciones si había que usar manos femeninas para producir.

Son interesantes las valoraciones al respecto. Los varones interrogados destacan la ocupación hogareña por parte de las mujeres mientras reproducen una visión tradicional que minimiza el trabajo femenino. De este modo se expresa que la labor femenina era menor en comparación con la masculina, por lo que raramente se la categoriza como trabajo (SUJETO 12, 2014. Información oral).

En cambio, acerca de sí mismas (como niñas o jóvenes, pero también acerca de sus madres o hermanas) las referencias mutan: si al principio se ubican entre la cocina y el patio, posteriormente confirman que estaban muy implicadas en tareas de gran esfuerzo

\footnotetext{
13 Sin embargo, no es una cuestión que remita particularmente a la etapa analizada. Se sugiere para profundizar al respecto la consulta de ATTADEMO, Silvia. El trabajo hortícola y la situación de la mujer en el Gran La Plata. In: SAUTU, Ruth; DI VIRGILIO, Mercedes; OJEDA, Gimena (comps.) Mujer, trabajo y pobreza en la Argentina. La Plata: Editorial de la Universidad Nacional de La Plata, 1999. p.163-170.
} 
físico (SUJETO 19, 2014. Información oral). Una localización por momentos difusa dialoga con el hecho evidente de que las mujeres no estancaban sus existencias en las casas, sino que se movían en zonas fronterizas donde lo doméstico y lo productivo se funden. No obstante, este rasgo transicional parece habilitar la invisibilidad. De este modo, las mujeres seleccionaban tomates por tamaño en el patio trasero de la casa; armaban paquetes de flores un poco más lejos, en el galpón. Pero no por eso dejaban de estar también en los invernaderos, regando o cortando flores; o en los surcos, levantando la cosecha de verduras hasta altas horas de la noche en temporada. También se las podía encontrar cargando lienzos o cajones (“jaulas”) de verduras en las camionetas junto con los varones, y conduciendo los vehículos o tractores (SUJETO 16, 2014. Información oral).

Tareas como las descriptas no eran inferiores ni necesariamente de menor intensidad que las que realizaban los varones, más bien constituían eslabones centrales de la cadena productiva familiar. Sucede que aquellas labores que eran más rudas y usualmente catalogadas como masculinas, cuando las realizaban las mujeres se las trataba como excepciones, anomalías que aparecían en el sistema de ocupaciones familiares cuando la situación lo requería. Sin embargo, no son pocas las entrevistas que señalan la presencia femenil como permanente. Como expone una entrevistada: “Cuando llegamos yo tenía que llevar la mercadería hasta la zona del cementerio porque no había asfalto, no había nada... ¡el sacrificio que se hacía!" (SUJETO 15, 2014. Información oral).

En efecto, la cantidad de tiempo que las mujeres dedicaban a las actividades en el campo no era minúscula. Este tipo de referencias se encuentra en variados relatos, y si bien es cierto que en temporada de cosecha la mano de obra familiar se usaba al máximo, la labor femenina no se inauguraba en ese momento. Si bien no todas las mujeres hacían los mismos trabajos que los varones, tampoco eran un grupo minoritario las que así lo hacían, ¿dónde radicaba, entonces, la diferencia entre ellas?

Parece claro que las mujeres de familias con larga experiencia en producciones rurales tenían tareas fijas, a veces con trabajos seleccionados por su "delicadeza", pero también otros de un alto esfuerzo físico. Es evidente que no todas cumplían estas funciones de igual modo. En algunas familias extensas estas situaciones se solucionaban porque los menesteres de la casa recaían en miembros femeniles que no podían 
desempeñarse con todo su potencial en el campo por limitaciones físicas o de otro tipo (SUJETO 13, 2014. Información oral). Se revela así una organización que ponderaba el aporte a la empresa y designaba a los eslabones más "frágiles" las tareas intramuros, maximizando el uso de manos disponibles.

No hay que desestimar que este tipo de organización también dialogaba con el bajo grado de capitalización que tenían las familias en los inicios, lo que las compelía a extremar el uso de fuerza de trabajo familiar. Pero incluso en las familias donde se contrataban peones la situación no difería sustancialmente, más bien se admitía el trabajo femenino regular, pero al mismo tiempo sin ser reconocido. Aunque el común denominador es que siempre se practicaban dentro de los límites del lote.

En efecto, las mujeres de extracción rural salían casi únicamente para concurrir a los almacenes que rodeaban las colonias, lo que evidencia circulaciones espaciales y usos del tiempo diferentes respecto de los varones. Las palabras de Vicenta ilustran la cuestión: "El hombre es diferente, agarra la bicicleta y se va a pasear y sale, pero ¿la mujer a dónde va? Yo tenía que estar adentro, hacia frio, tenías que estar adentro" (SUJETO 3, 2015. Información oral). En palabras de Josefina, argentina de origen japonés, su vida era “de la tranquera a la casa, de la casa a la tranquera”, incluso cuando ella se constituyó en cabeza del hogar cuando su padre no pudo hacerse más cargo (SUJETO 20, 2015. Información oral). ${ }^{14}$ Lo anterior señala hasta qué punto las mujeres tenían un espacio reservado y circunscripto, incluso como responsables de la producción. Estas situaciones no eran privativas de una comunidad étnica pues testimonios similares se replican.

Este estilo de referencias responde a una división sexual del trabajo que evidencia un reparto ideal de tareas que designaba a los hombres como encargados del lote y enlace entre la familia y la ciudad, en tanto que las mujeres aparecían como amas de casa. Como se ha dicho, éstas tenían fluidos tránsitos entre el hogar y la zona productiva, éste último aspecto no tan reconocido ni siempre auto reconocido. Las mujeres estaban capacitadas para hacer los trabajos supuestamente reservados a los varones y su aporte no era extraño, como también sucedía en otros tipos de explotaciones agrícolas. Por eso

\footnotetext{
${ }^{14}$ SUJETO 20. [Entrevista cedida a] Celeste De Marco, La Capilla (Florencio Varela), 15 mar. 2015
} 
irresuelta en algunos testimonios toma la forma de contradicciones o caracterizaciones difusas.

¿Cuál era la situación de las mujeres de orígenes urbanos que se habían radicado en estos espacios periurbanos colonizados? Sus familias, una vez adaptadas a la realidad rural de las colonias, eran más reticentes a incorporarlas al trabajo, más bien buscaban darles funciones hogareñas (SUJETO 21, 2013. Información oral; SUJETO 22, 2015. Información oral). Las esposas e hijas de productores que habían vivido en la ciudad, ingenieros agrónomos radicados en la colonia, comerciantes e incluso de los administradores, componían la muestra de este muy reducido conjunto. Una reflexión que merece este aspecto es acerca de los alcances que tuvo en la realidad el mentado "movimiento a la inversa" que proponía ubicar familiar urbanas en los campos periurbanos para arraigarlos, un fenómeno difícil de mensurar, pero sin dudas minoritario.

De modo que la experiencia femenina en las colonias parecía estar ligada, sobre todo, a las trayectorias familiares, características de la diversidad familiar predominante en este tipo de espacios. Así, las mujeres de familias rurales tenían un espacio de desempeño más circunscripto (casa-lote) con tareas más intensas, y aquellas de familias urbanas, en cambio, más disperso, con acceso más fluido a la ciudad y con tareas domésticas ("leves”).

La configuración del grupo doméstico también incidía. Más allá de sus orígenes, en las familias nucleares las decisiones se dirimían en el cuerpo familiar, siendo definitoria la figura paterna, lo que implicaba que las mujeres que componían este entramado aportaban regularmente desde roles subsidiarios definidos, como esposas e hijas. Aunque esta organización predominaba, había matices.

El caso japonés en "Colonia Urquiza", con sus grupos domésticos dotados de agregados familiares, muestra otros rasgos dentro de los roles femeninos. En esta 
comunidad los esposos y padres se ubicaban también a la cabeza de las decisiones del hogar, mientras que las esposas oficiaban como una suerte de "ayudas secundarias", aunque realizaban labores productivas diarias. Las hijas trabajaban a la par de sus hermanos varones en las labores del lote, como productoras o viveristas. Sin embargo, la nota distintiva era la abuela (usualmente paterna), una figura que gravitaba con fuerza pues sostenía y respaldaba las decisiones de su hijo. Era la voz autorizada, no para contradecir, sino para organizar. De hecho, con frecuencia a ella se dirigían los otros miembros para buscar permisos o dinero, pudiendo dispensar en ocasiones correctivos físicos (SUJETO 18, 2015. Información oral). En este sentido, la cohabitación era un aspecto muy importante para estos grupos.

De este modo, en la comunidad japonesa la abuela parecía ejercer, en tanto madre del jefe de familia, una autoridad que descansaba en un engranaje en el que lo femenino adquiere status cuando entra en una relación de poder respecto de otras mujeres. De este modo, la madre se convertía en una aliada del hijo al sosegar las posibles disidencias intramuros.

En suma, la ubicación dispersa de las mujeres responde a una operación que las invisibiliza mientras se evidencian lógicas propias de las relaciones de género que oscurecen ciertos matices, disputas o negociaciones. Sin embargo, el elenco femenino de las colonias configuraba un abanico heterogéneo en un marco en el que no faltaron reparos y cuestionamientos ante estructuras dadas, como también estrategias para enmendarlas.

\section{Reflexiones finales}

El presente estudio se orientó a reconstruir un particular sujeto de la historia rural argentina, como son aquellas familias que formaron parte de programas de colonización desarrollados durante la etapa peronista. A partir de una perspectiva que pondera los testimonios de los involucrados, en conjunto con otras fuentes, se concentró el interés en comprender sus experiencias. 
Las imágenes institucionales y de la prensa se presentan fragmentarias, donde las representaciones se cristalizan e impiden visualizar las porosidades de los roles y los vínculos, tanto como la dimensión familiar más allá de las idealizaciones. En ese sentido, el análisis de las entrevistas fue fundamental para reconstruir el mundo productivo y doméstico de los dos casos analizados.

En este sentido, los relatos construidos se enmarcan en una vida familiar y comunitaria determinada. Es importante tener en cuenta que, si bien las colonias fueron emprendimientos creados ad hoc para la llegada de familias rurales -por ende, no había un bagaje preexistente de experiencias comunes -, se advierte la existencia de condiciones sociales, productivas y económicas compartidas en las que pudieron anclar las memorias familiares.

Pero no sólo el nuevo espacio físico fue determinante. También lo fueron las trayectorias migrantes en las que la diversidad operó como denominador común para compartir desplazamientos, escisiones familiares, generaciones pasadas dejadas en otras tierras, nuevos comienzos y adaptaciones. La ruptura en los relatos intrafamiliares y la imposibilidad de resignificar vastos pasados en una identidad local común derivó en el uso de la experiencia colonizadora como un rasgo fundamental que se replica en los recuerdos, los tiñe y les da forma.

Los relatos apuntan hacia unos primeros tiempos complicados, en los que el arraigo estuvo unido a la cuestión productiva de forma inextricable. Del mismo modo en que la formación de las colonias indicaba una voluntad estatal para promover este tipo de emprendimientos, aparecen también aspectos controvertidos que apuntan a la carencia de condiciones básicas y acompañamiento apropiado que dejó a las familias en una situación de deriva. Aquí la construcción del hogar, como necesidad primaria pero también cargada de simbolismo es un nodo central de los testimonios.

En todo este escenario las memorias se estructuran en torno de la familia funcionando como un cuerpo: organizada, articulada, con sus miembros aportando a un objetivo compartido: la producción hortícola, florícola o tambera, sustento económico del grupo. Se divisa la acción mancomunada y el reparto de tareas como los pilares del 
funcionamiento del sistema. El reconocimiento del trabajo grupal -de forma recurrente en términos de "sacrificio" colectivo- es un rasgo que permea muchas entrevistas, y que bifurca los finales: algunos consideran que valió la pena porque los resultados estuvieron a la altura de los esfuerzos, en tanto que otros dejan entrever que malgastaron su fuerza y juventud. Sin duda esta valoración ex post se arraiga en los recorridos posteriores de cada entrevistado que dan sentido a sus historias.

Otro abordaje propuesto ha sido analizar las tareas según el género. Quedan en evidencia ciertas imágenes idealizadas que encorsetan los recuerdos de hombres y mujeres, y que al mismo tiempo reprimen la afluencia de valoraciones que ponderen la centralidad de los aportes de este último grupo. Finalmente, en los resquicios de los relatos, aparece el abanico de responsabilidades que la platea femenina afrontaba y cómo mujeres y niñas se ubicaban en el escenario familiar.

Las experiencias entre hombres y mujeres, en efecto, fueron distintas. La circulación diferencial y la circunscripción femenina al lote familiar así lo señalaban, experiencias que son percibidas de forma desigual en tanto las memorias replican el orden tradicional mujer-vida doméstica y hogar. Si la mujer estaba ligada al espacio íntimo y las fronteras de lo externo estaban delimitadas (muchas veces, por el alambrado del mismo lote), la vida masculina se percibe con mayores libertades, sobre todo de movimiento. $\mathrm{Y}$ estos recuerdos se expresan con fastidio o resignación por parte de las mujeres. La operación de invisibilizarlas evidencia las lógicas de las relaciones de género, oscureciendo ciertos roles, sus disputas o negociaciones. Sin embargo, las mujeres rememoran ciertos reparos y cuestionamientos ante esta estructura, como también estrategias para enmendarla.

Finalmente, los resultados apuntan a deshebrar el entramado diverso -y aun con aristas parcialmente desconocidas- de la vida familiar rural en Argentina al poner de relieve las experiencias de un grupo que habitó las fronteras del campo con lo urbano de la mano de proyectos oficiales. Quedan así planteadas numerosas similitudes respecto de otras familias contemporáneas en espacios netamente rurales, como también particularidades propias de los casos. 


\section{Bibliografia}

ARCHETTI, Eduardo; STOLEN, Kristie A. Explotación familiar y acumulación de capital en el campo argentino. Siglo XXI: Buenos Aires, 1975.

ARGENTINA. Cámara de Diputados de la Nación. Asambleas Legislativas. Diario de Sesiones: mensaje presidencial del 12 de octubre de 1963. Buenos Aires: [s.n.], 1963.

ARGENTINA. Ley Nacional $n^{\circ}$ 14.392, de 10 de diciembre de 1954. Régimen de Colonización. Arts. 29 y 30

ARGENTINA. Presidencia de la Nación. Subsecretaría de informaciones. La acción agraria en el Segundo Plan Quinquenal. Buenos Aires: [s.n.], 1953.

BALSA, Javier. El desvanecimiento del mundo chacarero: transformaciones sociales en la agricultura bonaerense, 1937-1988. Bernal: Universidad Nacional de Quilmes, 2006.

BIERNAT, Carolina. ¿Buenos o útiles? La política inmigratoria del peronismo. Buenos Aires: Biblos, 2007.

BORDIEU, Pierre. "L'esprit de famille". In: Raison practique sur la theorie de l'action. Seuil: París, 1994.

BUENOS AIRES. Cámara de Senadores de la Provincia de Buenos Aires (CSBA). Diario de Sesiones, 1947-1948, La Plata: Taller de Impresiones Oficiales, 1948. t. I, p. 31.

CARLI, Sandra. La memoria de la infancia: estudios sobre historia, cultura y sociedad. Buenos Aires: Paidós, 2011.

CIME. Colonización agrícola en Argentina. Planta- Piloto-Escuela Santa Catalina. Estudio elaborado para la Sección Colonización. Buenos Aires: IAO, Centro Documentazione Inédita, 1957. Fasc. 3666, p. 16

COLLIER, Jane, ROSALDO, Michelle y YANAGIZAKO, Sylvia. Is there a family?: new anthropological views. Thorne, Barrie y Yalom, Marilyn (ed.) Rethinking family. Boston: Northeastern University Press, 1992. p. 31-48.

DE MARCO, Celeste. Colonización agrícola en el periurbano bonaerense. Políticas, familias y memorias (1950-1980). 2018. 381 p. Tesis (Doctorado en Ciencias Sociales y Humanas), Universidad Nacional de Quilmes, Bernal (Buenos Aires, Argentina). Inédita, 2018a. 
DE MARCO, Celeste. Las (pequeñas) manos que trabajaron la tierra: vida infantil y recuerdos en el periurbano rural de Buenos Aires (Argentina, 1950-1960). Temáticas, Campinas: Universidad de Campinas, n. 47, p. 215-248, jun. 2018b.

DE MARCO, Celeste. Vida familiar en colonias tardías periurbanas: sociabilidad y condiciones de vida (Buenos Aires, Argentina: 1950-1970). Historia y Memoria, Boyacá: Universidad Pedagógica y Tecnológica de Colombia, v.12, p.185- 214, 2016.

DE RIZ, Liliana; TORRE, Juan Carlos. Argentina desde 1946. In: Lynch, John \& Cortés Conde, Roberto. Historia de la Argentina. Buenos Aires: Editorial Crítica, 2002.

ESPAÑOLES en Colonia Urquiza. El Día, La Plata, s/d, 7 ene. 1965

FE, Esperanza y iun tractor! El Día, La Plata, s/d, 31 ago. 1964

GIRBAL-BLACHA, Noemí. Políticas públicas para el agro se ofrecen. Llamar al estado peronista (1943-1955). Mundo agrario, La Plata, v.3, n. 5, p. 1-20, jul./dic. 2002

GUTIÉRREZ, Talía. Familia o familias rurales en la región pampeana. Representaciones y Condiciones de vida, 1930-1943. LÁZZARO, Silvia; BALSA, Juan Javier. Actores sociales, Estado y política en el agro pampeano, 1930-1943. Buenos Aires: Ciccus, 2012.

GUTIÉRREZ, Talía. La familia rural pampeana durante el peronismo, 1943-1955: agro y política en Argentina. GRACIANO, Osvaldo; OLIVERA, Gabriela. Actores sociales, partidos políticos e intervención estatal durante el peronismo 1943-1955. Buenos Aires: Ciccus, p. 403-448, 2015. t. 2.

HAREVEN, Tamara. Historia de la familia y la complejidad del cambio social. Revista de Demografía Histórica, Bellaterra (Barcelona), v. 13, n. 1, p. 99-150, 1995.

JELIN, Elizabeth. Familia y unidad doméstica: mundo público y vida privada. Buenos Aires: CEDES, 1984.

JELIN, Elizabeth. Pan y afectos: la transformación de las familias. Buenos Aires: FCE, 1998.

LÁZZARO, Silvia. El problema agrario durante el gobierno de Arturo Illia. Anuario del Centro de Estudios Históricos «Prof. Carlos S. A. Segreti», Córdoba, v. 2/3, n. 2/3, p. 63-80, 2002-2003.

LÁZZARO, Silvia. Estado, desarrollo y reforma agraria en la provincia de Buenos Aires (1958-1962). Anuario del Centro de Estudios Históricos «Prof. Carlos S. A. Segreti, Córdoba, v. 8, n. 8, p. 85-106, 2008. 
MATEO, Graciela. El gobierno de Mercante: expresión singular del peronismo clásico. In: REIN, Ranaan; SITMAN, Rosalie. (comp.). El primer peronismo: de regreso a los comienzos. Buenos Aires: Lumiére, 2005.

MUXEL, Anne. Individu et mémoire familiale. París: Collection Essais et Recherches, 1996. NORA, Pierre. Entre mémoire et histoire. In: Les lieux de mémoire: París: Gallimard, T. 1, p. $23-43,1984$

NOTAS de andar y ver. La Nación, Buenos Aires, p. 16, 17 dic. 1957

PERROT, M. (ed.) A history of private life: from the fires of Revolution to the Great War. Cambridge: Mass, 1990. v. 4.

RAPOPORT, Mario. Historia económica, política y social de la Argentina (1880-2003). Buenos Aires: Ariel, 2005.

SEGALEN, Martine. Memorias y recomposiciones familiares. Revista de Antropología social, Madrid, n. 18, p. 171-185, 2008.

STOLEN, Kristi Anne. La decencia de la desigualdad: género y poder en el campo argentino. Buenos Aires: Antropofagia, 2004.

TENEMBAUM, Juan.Orientación económica de agricultura argentina. Buenos Aires: Losada, 1946.

\section{Entrevistas}

SUJETO 1. [Entrevista cedida a] Celeste De Marco, Florencio Varela (Buenos Aires), 3 mar. 2014

SUJETO 2. [Entrevista cedida a] Celeste De Marco, Florencio Varela (Buenos Aires), 27 ene. 2015.

SUJETO 3. [Entrevista cedida a] Celeste De Marco, Florencio Varela (Buenos Aires), 27 ene. 2015

SUJETO 4. [Entrevista cedida a] Celeste De Marco, La Capilla (Florencio Varela), 16 may. 2015. 
SUJETO 5. [Entrevista cedida a] Celeste De Marco e Irene Cafiero, Melchor Romero (La Plata), 4 jul. 2015

SUJETO 6. [Entrevista cedida a] Celeste De Marco e Irene Cafiero, Melchor Romero (La Plata), 4 jul. 2015.

SUJETO 7. [Entrevista cedida a] Celeste De Marco e Irene Cafiero, Melchor Romero (La Plata), 24 mar. 2015.

SUJETO 8. [Entrevista cedida a] Celeste De Marco, Florencio Varela (Buenos Aires), 7 dic. 2014

SUJETO 9. [Entrevista cedida a] Celeste De Marco, La Capilla (Florencio Varela), 18 may. 2015

SUJETO 10. [Entrevista cedida a] Celeste De Marco, Florencio Varela (Buenos Aires), 25 feb. 2015

SUJETO 11. [Entrevista cedida a] Celeste De Marco, Florencio Varela (Buenos Aires), 23 feb. 2015

SUJETO 12. [Entrevista cedida a] Celeste De Marco, Florencio Varela (Buenos Aires), 2 oct. 2014

SUJETO 13. [Entrevista cedida a] Celeste De Marco, La Capilla (Florencio Varela), 22 feb. 2015

SUJETO 14. [Entrevista cedida a] Celeste De Marco, Florencio Varela (Buenos Aires), 23 feb. 2015

SUJETO 15. [Entrevista cedida a] Celeste De Marco, La Capilla (Florencio Varela), 15 mar. 2015

SUJETO 16. [Entrevista cedida a] Celeste De Marco, La Capilla (Florencio Varela), 3 mar. 2015

SUJETO 17. [Entrevista cedida a] Celeste De Marco, Florencio Varela (Buenos Aires), 3 mar. 2014

SUJETO 18. [Entrevista cedida a] Celeste De Marco e Irene Cafiero, Melchor Romero (La Plata), 24 mar. 2015 
SUJETO 19. [Entrevista cedida a] Celeste De Marco, Florencio Varela (Buenos Aires), 3 mar. 2014

SUJETO 20. [Entrevista cedida a] Celeste De Marco, La Capilla (Florencio Varela), 15 mar. 2015

SUJETO 21. [Entrevista cedida a] Celeste De Marco, Florencio Varela (Buenos Aires), 4 mar. 2013

SUJETO 22. [Entrevista cedida a] Celeste De Marco, Ranelagh (Buenos Aires), 16 may. 2015

Recebido em 25/04/2019 Aprovado em 24/07/2019

Universidade do Estado de Santa Catarina - UDESC Programa de Pós-Graduação em História - PPGH Revista Tempo e Argumento Volume 11 - Número 28 - Ano 2019 tempoeargumento@gmail.com 